\title{
Tonometer calibration in Brasília, Brazil
}

\author{
Calibragem de tonômetros em Brasília, Brasil
}

\author{
Fernanda Pires da Silva Abrão ${ }^{1}$ \\ Warley Alves Araújo ${ }^{2}$ \\ Geraldo Magela Vieira ${ }^{3}$
}

Trabalho realizado no UNIPLAC, School of Medicine - Brasília (DF) - Brazil.

${ }^{1}$ Acadêmica do $6^{\circ}$ ano de Medicina da Escola Superior de Ciências da Saúde - ESCS - Brasília (DF) - Brazil.

${ }^{2}$ Acadêmico do $6^{\circ}$ ano de Medicina da ESCS - Brasília (DF) - Brazil.

${ }^{3}$ Doutor, Professor de Oftalmologia da Faculdade de Medicina do Planalto Central - FAMEPLAC - Brasília (DF) - Brazil.

Address for correspondence: Geraldo Magela Vieira. SQS 306 - B1. G - Apto. 405 - Brasília (DF) CEP 70353-070

E-mail: gmvieiramd@yahoo.com

Recebido para publicação em 08.12.2008

Aprovação em 04.03.2009

\begin{tabular}{l} 
ABSTRACT \\
\hline Purpose: To determine calibration errors of Goldmann applanation \\
tonometers in ophthalmic clinics of Brasília, Brazil, and correlate the \\
findings with variables related to tonometers model and utilization. \\
Methods: Tonometers from ophthalmic clinics in Brasília, Brazil, were \\
checked for calibration errors. A standard Goldmann applanation to- \\
nometer checking tool was used to asses the calibration error. Only one \\
trained individual made all verifications, with a masked reading of \\
the results. Data on the model, age, daily use, frequency of calibration \\
checking and the nature of the ophthalmic department - private or public \\
- were collected and correlated with the observed errors. Results: One \\
hundred tonometers were checked for calibration. Forty seven percent \\
(47/100) were out of 1 mmHg range at least at one point checking. \\
Tonometers mounted to slit lamp, with less than 5 years, used in less \\
than 20 patients daily, that had a calibration check on a yearly basis, \\
and those from private office exhibit a lower rate of inaccuracy, but only \\
the first variable was statistically significant. Sixty one percent of to- \\
nometers on public hospitals were out of calibration. Conclusion: \\
Calibration of tonometers in the capital of Brazil is poor; those from \\
general hospitals are worst, and this fact can lead to inaccurate detection \\
and assessment of glaucoma patients, overall in the population under \\
government assistance.
\end{tabular}

Keywords: Intraocular pressure; Tonometry, ocular/instrumentation; Calibration; Equipment failure analysis; Glaucoma; Quality control

\section{INTRODUCTION}

The relevant role played by intraocular pressure (IOP) in glaucoma

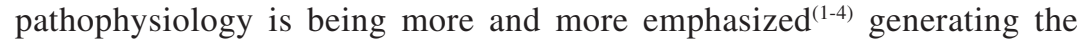
need to obtain its precise measurements both for diagnosis and follow-up of glaucomatous patients.

Since its introduction in the 1950s, Goldmann's applanation tonometry (GAT) has been considered the gold standard to check IOP ${ }^{(5)}$. Several factors influence IOP evaluation by GAT, such as time and number of checks $^{(6)}$, amount of fluorescein drops ${ }^{(7)}$, corneal curvature ${ }^{(8-9)}$, central corneal thickness ${ }^{(10-11)}$, among others. However, before questioning any other interfering factor, one should pay attention to instrument calibration.

Recent studies reported a high prevalence of calibration errors GAT ${ }^{(12-13)}$ which may confound the ophthalmologist regarding both the diagnosis and follow-up of glaucoma suspects and glaucoma patients.

Through personal information given to one of the authors (GMV) by a technician responsible for the maintenance of optical instruments in the Federal District (DF, where Brasília, capital of Brazil, a city of 2.5 million 
inhabitants is located), we heard of the low demand for tonometer calibration service in the region. We believe that despite of recent publications having emphasized the need for regular GAT checks, this problem may still have an important dimension in the Federal District.

The aim of this study is to verify GAT calibration in different clinics and hospitals of the Federal District, as well as possible factors related to calibration errors.

\section{METHODS}

A hundred Haag Streit ${ }^{\circledR}$ GATs from several public or private health care services of the Federal District were randomly tested in this transversal study.

Tonometer calibration was checked in position " 0 " ( $0 \mathrm{mmHg})$, " 2 " (20 mmHg) and "6" (60 mmHg) using a standard checking cylinder ${ }^{(14)}$ (Figure 1).

The highest and lowest reading in each of the checking points were identified according to the manufacturer's instructions manual ${ }^{(14)}$. The difference between the highest and lowest reading was considered the measure of the degree of the instrument play. The mid-point between the highest and the lowest reading was considered the true reading at the checked point.

Since the revolving drum had its movement limited in the position corresponding to $-2.0 \mathrm{mmHg}$, tonometers with readings less than $-2.0 \mathrm{mmHg}$ were considered to present a reading of $-2.0 \mathrm{mmHg}$. Tonometers with a checking error greater than or equal to $1.0 \mathrm{mmHg}$ in at least one of the three measuring points were considered as having a calibration error.

The following variables were also analyzed regarding their influences on calibration errors: model (mounted to slit lamp or removable), time of manufacture ( $\leq 5$ years or $>5$ years), number of daily attended patients $(\leq 20$ patients or $>20$ patients), calibration check frequency (at least annually or more than annually) and the nature of the health care faculty which used the tonometer (public or private).

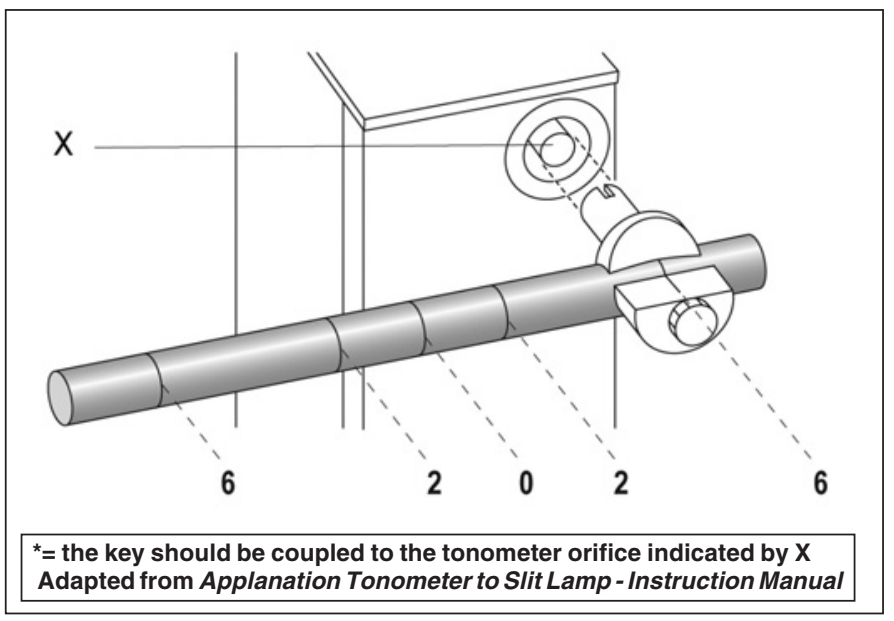

Figure 1 - Key for calibration check of Goldmann's applanation tonome with $0\left(\begin{array}{c}t \\ \mathrm{mmHg}\end{array}\right), 2(20 \mathrm{mmHg})$ e $6(60 \mathrm{mmHg})$ markers*
Data were collected from January to February 2007, all checks and interviews being performed by only one examiner who was trained previously for the task (FPSA). Reading of the checking measurements was masked and made by an independent observer (WAA).

Data regarding the age of the tonometer, calibration frequency and daily use were obtained from the administration staff of clinics or directly from the doctor who used the tonometer. Interviews were made always by the same examiner (WAA).

For the statistical analyses the chi-square test of the SPSS 14.0 program (SPSS Inc, Chicago, IL, USA) was used and $\mathrm{p}<0.05$ was considered a statistically significant association.

\section{RESULTS}

A hundred tonometers were assessed for calibration errors. Forty seven per cent (47/100) presented with calibration error regarding at least at one of the three checked reference points. Twenty-four percent (24/100) of the instruments presented a calibration error at position " 0 "; $27.0 \%$ (27/100) at position " 2 ", and $36.0 \%(36 / 100)$ at position "6".

Figure 2 shows the frequency of calibration error of the sample at each of the reference checking positions.

The relationship between calibration error and model, age, daily use, frequency of calibration error checks, and nature of service where the tonometer is used are shown in Table 1.

Among the evaluated associations, only the tonometer model is correlated in a statistically significant way with the frequency of calibration error $(\mathrm{p}=0.008)$. The other variables do not present a statistically significant association with the occurrence of calibration error (Table 1).

Means, respective standard deviations (SD) and variation coefficients (VC) of the measurements at positions " 0 ", " 2 " and " 6 " in slit lamp mounted and removable tonometers are described in Table 2. The greatest variation coefficient found was $5 \mathrm{mmHg}$ at position " 0 " and $10 \mathrm{mmHg}$ at both positions " 2 " an "6".

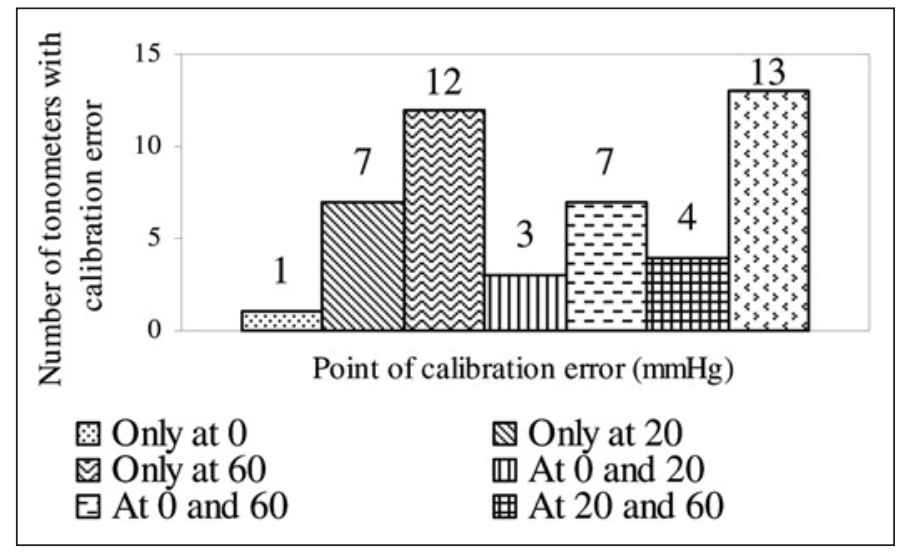

Figure 2 - Histogram of calibration error frequency at each of the three check points $(0,2$ and 6$)$ 


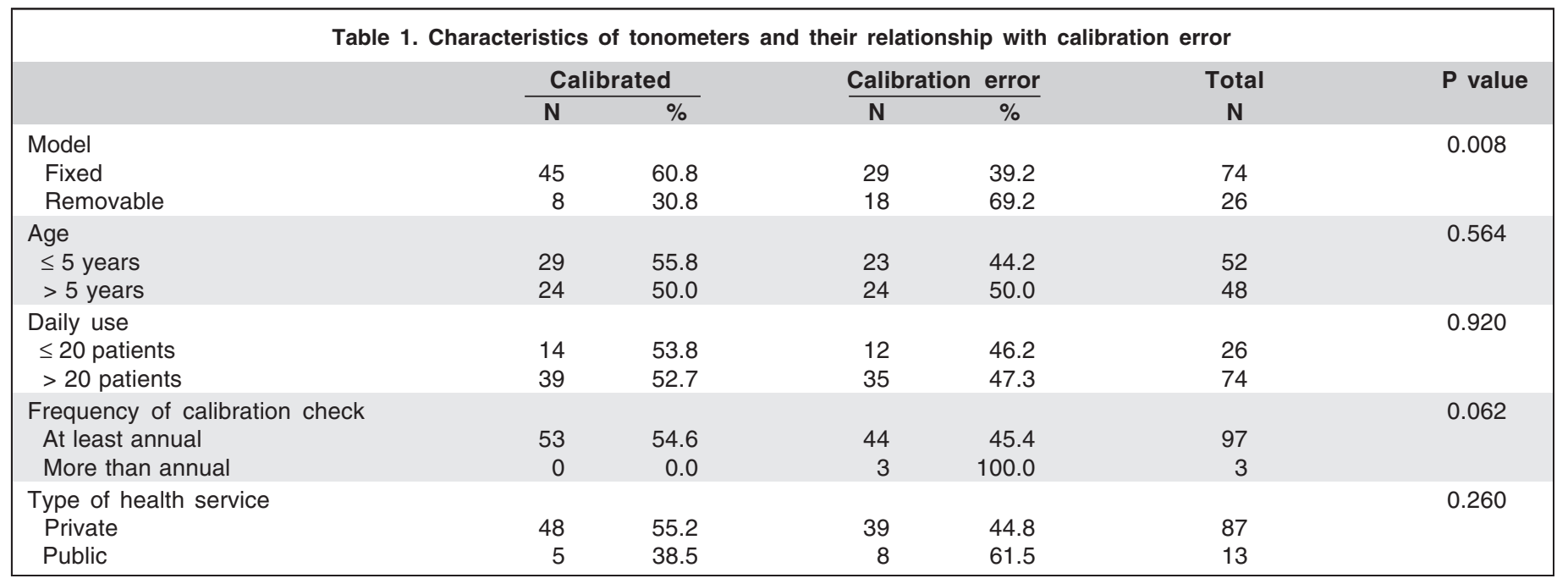

\begin{tabular}{|c|c|c|}
\hline Reading & $\begin{array}{c}\text { Fixed } \\
\text { Mean } \pm \text { SD }^{*} ; \mathrm{VC}^{+}\end{array}$ & $\begin{array}{c}\text { Removable } \\
\text { Mean } \pm \text { SD; VC }\end{array}$ \\
\hline $0 \mathrm{mmHg}$ & $1.54 \pm 1.10 ; 0.71$ & $1.54 \pm 1.17 ; 0.76$ \\
\hline $20 \mathrm{mmHg}$ & $1.51 \pm 1.93 ; 1.28$ & $1.62 \pm 2.08 ; 1.28$ \\
\hline $60 \mathrm{mmHg}$ & $1.05 \pm 1.52 ; 1.45$ & $1.73 \pm 2.09 ; 1.21$ \\
\hline \multicolumn{3}{|c|}{${ }^{*} \mathrm{SD}=$ standard deviation; $\mathrm{VC}^{+}=$variation coefficient } \\
\hline
\end{tabular}

\section{DISCUSSION}

Goldmann applanation tonometer mechanism comprises a checking prism made of an organic lens whose extremity turned towards the eyeball is plane with rounded borders in order to avoid corneal lesions. In contact with cornea, the prism's plane surface exerts a pressure controlled by the examiner by turning a graded drum which makes the tonometer shaft move, thus determining the pressure of the prism to the patient's eye. The drum is turned until an $7.354 \mathrm{~mm}^{2}$ area of corneal surface is flattened. The force needed to obtain this applanation is converted into pressure and IOP value may then be determined ${ }^{(14)}$.

Calibration error of a tonometer leads to an error in IOP reading. The diagnostic classification of a patient as normal, glaucomatous or glaucoma suspect, as well as the determination of the target IOP, may be impaired to a certain degree ${ }^{(15-17)}$.

In dealing with a mechanical system, GAT needs periodical calibration. The manufacturer's manual recommends the frequency of calibration check to be monthly at the measurement points corresponding to $0 \mathrm{mmHg}, 20 \mathrm{mmHg}$ and $60 \mathrm{mmHg}$. For this purpose, a specific key supplied by the manufacturer is used to verify whether the instrument is calibrated or not (Figure 1) ${ }^{(14)}$.

The manufacturer considers $0.5 \mathrm{mmHg}$ as an acceptable error margin at $0 \mathrm{mmHg}$ and $20 \mathrm{mmHg}$ measurements, and
$1.0 \mathrm{mmHg}$ at $60 \mathrm{mmHg}$ measurement ${ }^{(14)}$. The present study considers a tonometer with calibration error those with check error greater than or equal to $1.0 \mathrm{mmHg}$ in at least one of the three measurement points.

In our study, $47.0 \%$ (47/100) presented a calibration error in at least one of the three check points. In addition, 40 GATs presented a degree of the instrument play over $1.0 \mathrm{mmHg}$ at position "2", exceeding $4.0 \mathrm{mmHg}$ in five of these instruments. At position " 6 ", there were five instruments with a calibration error greater than $4.0 \mathrm{mmHg}$, one of which presented $10.0 \mathrm{mmHg}$ as a degree of the instrument play. On the other hand, only one tonometer showed an error greater than $4.0 \mathrm{mmHg}$ at position " 0 ".

Our data demonstrate that calibration errors did not present an internal consistency among the three studied check points, showing variation in magnitude among them. Conversely, the observed high variation coefficients reveal a quite heterogeneous sample, with many reading variation between tonometers at the same check point.

Errors less than $1.0 \mathrm{mmHg}$ may not have a great influence on clinical decision ${ }^{(18)}$, but we found several instruments with variation over this value, which may probably lead to an error in IOP readings of patients, with serious consequences, overall in those with advanced glaucoma ${ }^{(19-20)}$.

Wessels \& Oh in a sample of 175 applanation tonometers mounted to a slit lamp, and checking the calibration only at position "2", found $18.3 \%$ of instruments with calibration error with a mean error of $0.43 \mathrm{mmHg}$ (varying from -0.29 to $1.44 \mathrm{mmHg})^{(12)}$. The numbers found by these authors are clearly inferior to those observed in our study.

In a similar investigation conducted in Recife, PE, in northeastern Brazil, which used the same criteria for calibration error as that of our study, Costa et al. found $12.7 \%, 25.3 \%$ and $10.1 \%$ tonometers with calibration errors at positions " 0 ", "2", and " 6 ", respectively ${ }^{(13)}$. In that study, it was observed that $25.3 \%$ of tonometers presented a calibration error, a quite 
lower number than that found in our research. In an Ophthalmologic Center of Vancouver, Canada, with a sample of 25 instruments, calibration errors up to $1.0 \mathrm{mmHg}$ were classified as clinically irrelevant. Even so, the obtained percentage of tonometers with calibration error was $24 \%{ }^{(21)}$, still a quite smaller number than that found in the present study.

Of the removable tonometers, $69.2 \%$ had calibration error, while this index was $39.2 \%$ in slit lamp mounted instruments. This numbers are higher compared to that obtained by Costa et al., where percentages were $39.0 \%$ and $10.5 \%$, respective$1 y^{(13)}$. In the same way, Wessels \& Oh observed $33.0 \%$ and $12.6 \%$, respectively, confirming a significant relationship between the tonometer model and calibration ${ }^{(12)}$.

Means of degrees of the instrument play and the respective standard deviations were greater in removable tonometers when compared to fixed ones, a fact also verified in Wessels \& Oh's study who observed error and standard deviation means of $0.36 \pm 0.65$ for slit lamp mounted models and $0.60 \pm 0.84$ for removable ones. This demonstrates that more calibration errors occur and this tends to be greater in removable tonometers. This fact, as suggested, may be explained by the handling and shocks to which the removable tonometers are exposed ${ }^{(12)}$.

Despite the fact that half of tonometers over 5 years old were calibrated, they presented proportionally more calibration errors when compared to those with less than 5 years, which is in agreement with Wessels \& $\mathrm{Oh}^{(12)}$. This may be linked to the fact that, due to a longer exposure time, older tonometers are more subject to dust and other debris accumulation in their mechanism along time, determining increase in resistance to movement and culminating in loss of precision ${ }^{(12)}$.

Little difference was observed between calibration of tonometers used for twenty or less patients per day as compared to those used for a higher number of patients. These data agrees with those obtained by some authors ${ }^{(13)}$, but contradict others ${ }^{(12)}$.

Most tonometers are checked at least annually, however, all three tonometers which were checked with a frequency greater than annual presented calibration error, with two of them showing inaccuracy at the three evaluated positions. Our interview regarding calibration frequency was conducted by one of the researchers by personal communication, which can cause some constraint and therefore is subjected to a bias. This is represented by the great number of tonometers with calibration error in contrast to the high calibration check frequency informed in our interview. In the United Kingdom, a study conducted using questionnaires sent by mail to ophthalmologists showed that $85 \%$ of them never tested the calibration of their tonometers ${ }^{(22)}$.

It can be seen that there is a greater proportion of tonometers with calibration error in public health services when compared to private ones. This probably occurs due to the precarious conditions of instrument maintenance in Brazilian public health service and, naturally, to the excessive use. Unfortunately, the sample of this last group was too small to obtain a possible statistically significant association.
In consonance with the manual of the instrument manufacturer $^{(14)}$, some authors ${ }^{(21-22)}$ suggested that calibration check frequency of tonometers should be monthly. According to data of the present research, we believe that a better awareness by ophthalmologists is needed regarding the importance of performing the simple procedure of periodically checking the tonometers, especially the models not fixed to the slit lamp. The great errors observed overall in public hospital of Federal District demonstrate the need to establish routine procedures in ophthalmic services of Brasília, determining the time when tonometer check should be performed and the person responsible for this task.

\section{CONCLUSION}

It was observed that removable tonometers with over five years of use, attending more than twenty patients daily, checked at time intervals over one year and which are used in public health services are proportionally those with more calibration errors.

The high prevalence of tonometers with calibration error in health services of the Federal District shows the importance of instruments frequent calibration checks to guarantee a correct follow-up of the patients, specially those with glaucoma.

\section{RESUMO}

Objetivos: Determinar os erros de calibração dos tonômetros de aplanação de Goldmann em clínicas oftalmológicas de Brasília, Brasil, e correlacioná-los a variáveis relativas ao modelo e à utilização dos aparelhos. Métodos: Tonômetros de clínicas oftalmológicas de Brasília tiveram a calibragem aferida usando um cilindro padrão fornecido pelo fabricante dos aparelhos. Todas as aferições foram realizadas por um só examinador previamente treinado e a leitura das medidas foi mascarada por um observador independente. As medidas foram correlacionadas ao modelo, idade, utilização diária e frequência de aferição da calibração dos tonômetros, bem como o serviço em que o aparelho era utilizado - público ou privado. Resultados: Cem tonômetros foram avaliados. Quarenta e sete por cento (47/100) apresentaram erros de leitura maiores ou iguais a $1 \mathrm{mmHg}$ em pelo menos um ponto de aferição, sendo considerados descalibrados. Tonômetros fixos à lâmpada de fenda, com menos de 5 anos de fabricação, usados em menos de 20 pacientes por dia, que tinham a calibragem aferida ao menos anualmente e que eram utilizados em clínicas privadas apresentaram menos descalibragem, porém apenas a primeira variável foi estatisticamente significante. Sessenta e um por cento dos tonômetros de hospitais públicos estavam descalibrados. Conclusões: A calibragem de tonômetros avaliados em Brasília é precária. A situação é pior nos aparelhos dos hospitais públicos, podendo levar a erros na detecção e no acompanhamento de pacientes com glaucoma atendidos nesses serviços. 
Descritores: Pressão intraocular; Tonometria ocular/instrumentação; Calibragem; Análise de falha de equipamento; Glaucoma; Controle de qualidade

\section{REFERENCES}

1. Hollows FC, Graham PA. Intraocular pressure, glaucoma, and glaucoma suspects in a defined population. Br J Ophthalmol. 1966;50(10):570-86.

2. Bengtsson B. The prevalence of glaucoma. Br J Ophthalmol. 1981;65(1):46-9.

3. Klein BE, Klein R, Sponsel WE, Franke T, Cantor LB, Martone J, Menage MJ. Prevalence of glaucoma. The Beaver Dam Eye Study. Ophthalmology. 1992;99(10):1499-504.

4. Heijl A, Leske MC, Bengtsson B, Hyman L, Bengtsson B, Hussein M; Early Manifest Glaucoma Trial Group. Reduction of intraocular pressure and glaucoma progression: results from the Early Manifest Glaucoma Trial. Arch Ophthalmol. 2002;120(10):1268-79. Comment in: Arch Ophthalmol. 2002;120(10):1371-2. JAMA. 2002;288(20):2607-8. Optom Vis Sci. 2002;79(12):741-2.

5. Goldmann H, Schmidt T. Über applanationstonometrie. Ophthalmologica. 1957; 134(4):221-42.

6. Moses RA. The Goldmann applanation tonometer. Am J Ophthalmol. 1958; 46(6):865-9.

7. Grant WM. Fluorescein for applanation tonometry: more convenient and uniform application. Am J Ophthalmol. 1963;55:1252-3.

8. Mark HH. Corneal curvature in applanation tonometry. Am J Ophthalmol. $1973 ; 76(2): 223-4$

9. Holladay JT, Allison ME, Prager TC. Goldmann applanation tonometry in patients with regular corneal astigmatism. Am J Ophthalmol. 1983;96(1):90-3.

10. Ehlers N, Bramsen T, Sperling S. Applanation tonometry and central cornea thickness. Acta Ophthalmol (Copenh). 1975;53(1):34-43.

11. Wolfs RC, Klaver CC, Vingerling JR, Grobbee DE, Hofman A, de Jong PT.
Distribution of central corneal thickness and its association with intraocular pressure: The Rotterdam Study. Am J Ophthalmol. 1997;123(6):767-72.

12. Wessels IF, Oh Y. Tonometer utilization, accuracy, and calibration under field conditions. Arch Ophthalmol. 1990;108(12):1709-12.

13. Costa RT, Barreto RBP, Lopes FP, Lira RPC. Análise da aferição dos tonômetros de aplanação de Goldmann em serviços oftalmológicos de Recife. Arq Bras Oftalmol. 2004;67(2):267-70.

14. Haag-Streit International. Applanation Tonometer to Slit Lamp. Instruction Manual. Koeniz: Haag-Streit Ag Ophthalmic Instruments; 2005.

15. The Advanced Glaucoma Intervention Study (AGIS): 7. The relationship between control of intraocular pressure and visual field deterioration. The AGIS Investigators. Am J Ophthalmol. 2000;130(4):429-40. Comment in: Am J Ophthalmol. 2000;130(4):490-1.

16. Gordon MO, Beiser JA, Brandt JD, Heuer DK, Higginbotham EJ, Johnson CA et al. The Ocular Hypertension Treatment Study: baseline factors that predict the onset of primary open-angle glaucoma. Arch Ophthalmol. 2002;120(6):714-20; discussion 829-30. Comment in: Arch Ophthalmol. 2004;122(7):1088-9; author reply 1089 .

17. Seddon JM, Schwartz B, Flowerdew G. Case-control study of ocular hypertension. Arch Ophthalmol. 1983;101(6):891-4.

18. Sandhu SS, Chattopadhyay S, Birch MK, Ray-Chaudhuri N. Frequency of Goldmann applanation tonometer calibration error checks. J Glaucoma. 2005; 14(3):215-8

19. Le A, Mukesh BN, McCarty CA, Taylor HR. Risk factors associated with the incidence of open-angle glaucoma: the visual impairment project. Invest Ophthalmol Vis Sci. 2003;44(9):3783-9.

20. Medeiros FA, Pinheiro A, Moura FC, Leal BC, Susanna R Jr. Intraocular pressure fluctuations in medical versus surgically treated glaucomatous patients. J Ocul Pharmacol Ther. 2002;18(6):489-98.

21. Chuo JY, Mikelberg FS. Calibration errors of Goldmann tonometers in a tertiary eye care centre. Can J Ophthalmol. 2007;42(5):12-4.

22. Kumar N, Jivan S. Goldmann applanation tonometer calibration error checks: current practice in the UK. Eye. 2007;21(6):733-4.

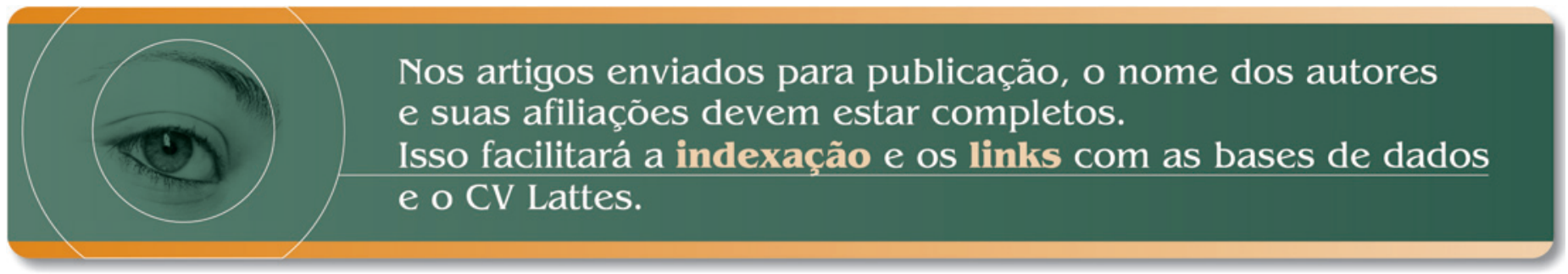

